\title{
Role of Women in Politics: A Study of Political Participation in Pakistan
}

\author{
Dr. Allauddin \\ Ph.D from School of International Relations and Public Affairs, \\ Shanghai International Studies University, \\ Shanghai China. \\ allauddin_kakar@yahoo.com \\ $\&$ \\ Dr. Shahida Habib Alizai \\ Assistant Professor, \\ Gender and Development Studies Department \\ University of Blochiistan Quetta. \\ shahidadostain@gmail.com \\ $\&$ \\ Zareen khan Rind \\ Assistant professor, \\ Abida Tehrani Sindh Development Studies Center \\ University of Sindh \\ Jamshoro - Pakistan \\ Zareenrind01@hotmail.com
}

\begin{abstract}
This study explores the Political participation of women in Pakistan. Through the political history of Pakistan, it is apparent that the role of women in politics has not been substantial nevertheless their population size. This research paper highlights women's political participation and representation in Pakistan's politics. Women's role in the political process will be explored from a historical and current perspective. Historically, women's role as a representative in the legislative assemblies of Pakistan remained limited. However,
\end{abstract}




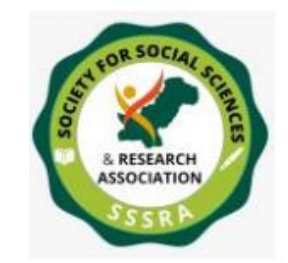

during the last two decades, significant measures have been made to enhance women's political representation in the country. In Pakistan, the voting turnout of women has always been lower as compared to the male counterpart during all the general elections held in Pakistan. The turnout of women's voters will be explored in the general elections of the country. The research also elaborates on the factors affecting women's political participation in the country. The research paper underscores social impediments that have posed challenges for women to become an important part of Pakistan's political system. Political participation is not limited to get representation in legislative assemblies. It consists of a wide range of political activities such as role as a voter, become a member of a political party, etc.

Key Words: Political Participation, Political system, legislative assembly, women, Pakistan.

\section{Introduction}

Women in Pakistan have been playing a pivotal role in Politics. Since Pakistan's independence, the role of women has been central to the domain of politics in the country. Women constitute $48.52 \%$ of the population of Pakistan (World Bank, 2019) and play important role in all spheres of life in Pakistani society. The role of women in the domain of politics has been neglected as compared to their size in the population of the country. There is merely $15 \%$ of women representation throughout the world (UNDP, 2005).

Women's political empowerment is a global issue. In developing countries of the world, it remains a problem yet to be resolved. Pakistan, being a developing country, is also facing the issues of gender inequalities against women in the political sphere. The constitution of Pakistan guarantees women's fundamental rights which also includes political rights. In the constitution of Pakistan, the human rights proclamation can be found from the preamble onwards. Article 25 of 
the chapter of fundamental rights underscores the principles of equality of women in Pakistan's constitution. (Women Development Departmnet, 2021).

Before the independence of Pakistan, Muslim women were part of rallies and processions of the All India Muslim League. The constitution of Pakistan encourages the role of women in the political affairs of the country. Political parties have formed women's wings which encourage women's political participation in the country. However, their representation still lags far behind as compared to male counterpart (Elashi, 2014). During the last two decades, the successive governments in Pakistan have taken serious steps to increase women's representation in legislative assemblies. These decades witnessed an increasing role of women in the political affairs of the country. However, some areas still need the special focus of the government.

Leaders like Fatima Jinnah played an inspirational role in politics. In 1988, Pakistan became the first country in the Muslim world which was led by a women Prime Minister-Benazir Bhutto. Pakistan has made significant progress in empowering women in the political sphere. Though Pakistan was led by a women Prime Minister twice in its political history and numerous other key positions served women, it is still among the countries where the political representation of women is low" (Kamray, 2020, September 15).

Pakistan has taken steps to enhance women's role in politics and create an encouraging environment for women to participate in politics. Sustainable Development Goals of Pakistan include commitments to ensure gender equality and eliminate gender discrimination within Pakistani society (Khan \& Naqvi, 2020). However, the current scenario is still not encouraging when it comes to women's political participation.

\section{Research Methodology}

This research paper is based on the design of exploring the facts associated with women's political participation in Pakistan. This study design is based on a 


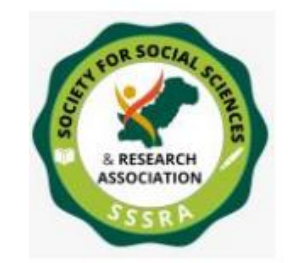

systematic approach to conduct research to attain quality. Adequate data were found for conducting this study with the use of secondary sources. Therefore, the author did not felt the need to use primary sources of data collection. The secondary sources used for conducting this study range from scholarly books, research journals, magazines, newspapers, online reports, and official reports.

\section{Literature Review}

In politics, women have frequently remonstrated against the non-serious attitude of media coverage of female politicians which has been given minimal coverage as compared to men (Kahn, 1994). In media, women are often discussed in terms of their personality and physical appearance rather than policy, capability, and political vision. The portrayal of women in media is more focused on the dress and physical beauty than on substance and action. This type of media coverage is mainly due to prevent the voters to recognize their role as a potential candidate. (Kahn, 1994). It is noted that their role is portrayed as relevant to issues such as abortion or child care, mainly issues that are linked with women's traditional role as mothers. This negative and limited role of women political leaders or candidates makes them out as being a weaker leaders with no view on significant issues. This portrayal of women in media which lacks political agency makes them less likely to be re-elected. Moreover, their male counterpart does not respect them and make it more complicated and difficult for them to pass legislation of their will and requirements (Scheidt, 2014).

\section{Development of Women's Representation in Pakistan}

Women were at the forefront of the Pakistan movement. They were side by side with men in the struggle for achieving a separate homeland for the Muslims. Women were organized under the leadership of Fatima Jinnah and played a crucial role in the Pakistan movement. However, this political enthusiasm for a long period did not translate into effectual political participation. Pakistan's first constituent assembly, which worked from 1947 to 1954 had only two women out of 79 members. Moreover, the indirect election held in the year 1956 also witnessed no 
women's success as a member of the legislative assembly. The constitution of 1956, besides reserved seats also endorsed the principle of women suffrage along with reserved seats. (Bano, 2009).

The election of 1956 though did not witness considerable numbers of women's seat, but the decision of Fatima Jinnah to contest the presidential election against Ayub Khan was the most crucial though resulted in the former's defeat. Between 1962 and 1965, the number of women parliamentarians was only 8 out of 156 parliamentarians. During the 1965-1969 term, these numbers further lessened to 6 .

The ear of Zulfiqar Ali Bhutto witnessed significant developments in terms of women's representation in politics. Nine women contested the general election held in 1970. From the year 1977, the number of female politicians contesting and winning national assembly seats witnessed a gradual increase and it reached to highest in numbers in 2008. (Latif, Ahmed \& Abdullah, 2020).

In Zia's party-less elections held in 1985, 15 women contested the election, but merely one got successful. Three years after this, the number of successful candidates rose to four included two leading women politicians Benazir Bhutto and her mother Nusrat Bhutto. The year 1997 witnessed the participation of 34 women in the election, but candidates who secured seats were still few with six women who could only be elected.

The Regime of Musharraf witnessed significant developments in women's political empowerment. The number of women's reserved seats were increased in both national and provincial assemblies. It was a landmark measure to reserve 17\% representation for women in both national and provincial legislators. From 2002 to 2007, the eleventh assembly had 69 women members out of 343 (Graff, 2003).

Promisingly, seventy female candidates contested the 2002 election and 13 were successful in winning seats. This positive trend of increasing representation of women in legislative assemblies' continued with 16 out of 64 female candidates got elected in general elections held in 2008. Additionally, the election act 2017 is 


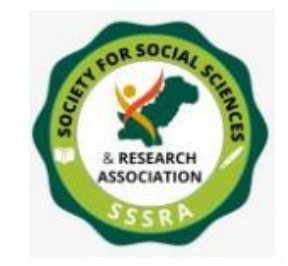

another landmark introduction to enhance women's seats in legislative assemblies. The act which bound all parties to give at least $5 \%$ of their party tickets to female candidates, was an enormously positive measure to promote women's political participation in the country. (Azhar \& Basit, 2020). The Election Commission of Pakistan under its act 2017 has now empowered to declare results invalid in constituencies where female voters turn out less than $10 \%$ is. This is an important measure to enhance women's role in the political system. As a result of this act, the election of Pakistan has canceled by-election in 2018 in lower Dir in Khyber Pakhtunkhwa on account of zero levels of female voter turnout. Re-election was held and the females cast over 1000 votes. This is a significant beginning that would result in more positive outcomes (Dawn Editorial, 2020).

However, the ground realities remained unchanged, with $45 \%$ of the parties contesting the following year's elections did not field a signal women candidate. Although in the general elections of 2018 the number of female candidates was highest with 182 female candidates contested the election, but the number of successful candidates could not exceed the 2008 results and was only 15 .

The political culture of Pakistan is based on patriarchal culture. Women are given fewer opportunities as men dominate the structure. However, Pakistan is making progress in promoting women's role in democracy. Pakistan has set goals to ensure gender equality and women empowerment, thus promoting its role in every sphere of life including politics (UN Women). In the political sphere, the past two decades have witnessed noteworthy developments in terms of the political participation of women. During the same period, women's political participation has also increased in legislative bodies. The changing trends in women's political participation are due to several factors, such as the legal commitment of Pakistan at the global level and the formulation of policies for women empowerment. During the last two decades, Pakistan has taken many legislative actions to enhance women's representation at the local, provincial and national levels. The election commission order of 2002, political party's order of 2002, the allocation of reserved seats for women in national and provincial assemblies, and non-Muslims Rules of 2002 are measures that have contributed to enhancing the political participation of women. 


\section{Current Trends of Women's Political Participation}

To explore the present scenario of women's political participation, three main areas will be highlighted: 1 party ticket awarded to women to contest an election, 2 total representation of women in provincial and national legislatures, 3 successful women candidates in the provincial and national assembly. Besides, in this section, the study explores the number of elected women to general seats.

Although women actively participated in the general election of 2008, yet they were not given due representation from political parties. The total number of women candidates nominated by political parties stood at $3.5 \%$, on the other hand around $96.5 \%$ of the candidates were men. Such a low level of women's representation in the election reflects low confidence on the part of political parties. The proportion of women in decision-making positions in the political parties declined (UNDP, 2005).

Political participation of women is mainly limited to casting votes and they are exploited by political party's political functions and election campaigns. Although political parties have created women's wings, these remain to fulfill mainly representative functions and have a limited role in policymaking.

The executive director of 'Women in Struggle for Empowerment (WISE) stated that "Pakistan, India, Bangladesh, and Sri Lanka have all been ruled by women leaders in the past but the representation of women at other levels in all these countries is still very low as compared to many other countries. In South Asia, Nepal is on top with 32.7 percent women in the parliament, followed by Afghanistan at 27.3 percent, Bangladesh at 20.6 percent, Pakistan at 20.2 percent, Bhutan 14.9 percent, India 12.6 percent, Sri Lanka 5.3 percent, and the Maldives 4.7 percentage" (Dawn Staff Reporter, (2020, January 22).

Nonetheless, it is a significant development that women participated massively for national assembly general seats in the general election of 2013 in comparison with 


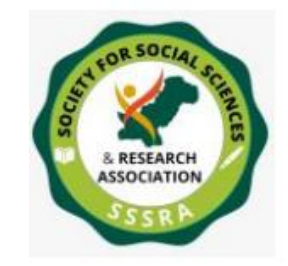

2008. Furthermore, women's participation in an election from remote areas was also a positive development in women's political participation. In the general election of 2013, women belonging from economically deprived parts of province Sindh also participated. These women from relegated and economically neglected groups sought to raise their voices in the mainstream political system raise their voices for those issues being neglected by male politicians such as women's rights.

Notwithstanding this rather mixed track record on the development of political participation of women in politics, especially about women's role in political parties, Pakistan is a prominent example of women's political role for the Muslim world. For instance, Benazir Bhutto became the first-ever women prime minister of a Muslim state in 1988. Likewise, Fahmida Mirza became the first women speaker of a national assembly of a Muslim country. Besides, around 100 women members became a member of Pakistan's national legislative assemblies in the general election of 2013. Women served key federal ministries like especial education, health, social welfare, Information and Broadcasting, and foreign affairs respectively.

Though gender discrimination is a hurdle in the progress of women's empowerment in the political domain, the statistics on women's representation reflect progressive trends. It shows that around $20 \%$ of the total legislative assembly's members were female. The general election of 2018 also witnessed the same result. In the election of 2018, women secured 8 seats while contesting general seats along with 60 reserved seats (Free and Fair Election Network, 2018).

In the general election of 2018, the number of women elected on general seats was less than before. This was the first general election held after the Election Act 2017 which guarantees $5 \%$ tickets of political parties to women. The act was highlight appreciated by social activists and global donor organizations. The Act is considered a support to the democratic process (Khan \& Naqvi, 2020) 
Women Position in National Assembly in 2018 Elections

\begin{tabular}{|lccr|}
\hline $\begin{array}{l}\text { Party } \\
\text { Percentage }\end{array}$ & General Seats & Reserved seats & Total \\
\hline $\begin{array}{l}\text { PTI } \\
48\end{array}$ & 3 & 29 & 32 \\
\hline $\begin{array}{l}\text { PPP } \\
16\end{array}$ & 3 & 8 & 11 \\
\hline $\begin{array}{l}\text { PML (N) } \\
25\end{array}$ & 1 & 16 & 17 \\
\hline $\begin{array}{l}\text { Others } \\
12\end{array}$ & 1 & 7 & 8 \\
\hline
\end{tabular}

Source: (Free and Fair Election Network, 2018)

In the general election of 2008, the average turnout of voters was $44.6 \%$. According to a calculation made by FAFEN, the turnout of $48.2 \%$ was based on 174 constituencies in Pakistan. The possibilities of anomalies were also reported in $23 \%$ of the constituencies as the turnout was recorded $100 \%$ or even more than this. Though the security situation was not satisfactory and the presence of anomalies, the turnout of the voters in the election was outstanding. The turnout of voting varied in different types of polling stations based on gender i.e. Low turnout was reported in female polling stations, about $39.7 \% \%$ in comparison with the male polling stations which was reported with $49.8 \%$. In Khyber Pakhtunkhwa, the turnout of the female voters was reported lowest.

In the general elections of 2018, the overall national voter turnout stood at $55 \%$. This marked an improvement in the country's historically low turnout, which hardly exceed $44 \%$. The turnout for female voters was an unprecedented $40 \%$ of all votes. The turnout of women voters is deemed remarkable, but still requires encouragement in the male-dominated society (UN Women, 2013).

In the general election 2018, the turnout of the female voters was also lower in comparison with the male voter's turnout. The ratio of female voter's turnout was $46.89 \%$ in general elections of national assembly while the male voter's turnout 


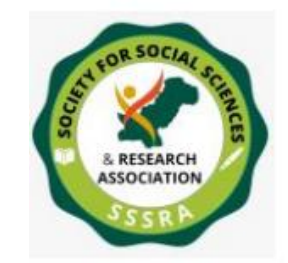

was reported 56.07\%. In Punjab, the ratio of female voter's turnout was $40.03 \%$ as compared to $48.87 \%$ of male voter's turnout. In Sindh, the turnout of female voters was reported $42.46 \%$ as compared to $50.87 \%$ of male voter's turnout. In Khyber Pakhtunkhwa, the female polling was reported with low turnout. The ratio of voters' turnout for females was $32.96 \%$ whereas $51.77 \%$ for males. In Balochistan, it was reported $40 \%$ as compared to $48.87 \%$ for males (Free and Fair Election Network, 2018). Nearly all constituencies in the general election 2018 were reported with more than $5 \%$ of women voter turnout (Khan, 2020, October 9).

Chairman 'National Commission on the Status of Women (NCSW) after the general election of 2018 stated "Many times what we have seen is that general political activism provides the space for women to also progress". She added that "The general elections of 2018 were very significant from the point of view of women. It was also the first election under the new Elections Act 2017 which has specific provisions for the women's fuller participation not only for the mandatory quota for tickets for women in political parties and 10pc minimum turnout of women in a constituency to declare a result valid but also for its inclusion of persons with disabilities and transgender and institution of the postal ballot" (Kazmi, 2018, December 14).

Position of Women in National Assembly after Elections 2018

\begin{tabular}{|ccc|}
\hline & Men & Women \\
\hline Regions & 48.87 & $40.03 \%$ \\
\hline Punjab & 50.87 & $42.46 \%$ \\
\hline Sindh & 51.77 & $32.97 \%$ \\
\hline KPK & 47.87 & $40.03 \%$ \\
\hline Balochistan & 62.91 & $53.71 \%$ \\
\hline ICT
\end{tabular}

Source: (Free and Fair Election Network, 2018)

In an important move, the Election Commission of Pakistan has mandated that each province of the country have at least one female district election commissioner. This is a significant move and will hopefully play create encouraging political 
environment for women to take part in the political affairs of the country, strengthening the practice of democratic decision-making. The constitution of the country has guaranteed the political rights of women, but still fewer women make their presence in polling stations on the polling day, as compared to their male counterparts. Women being half of the country's population, are often treated as second-class citizens due to hurtful and pervasive social and cultural norms that affect every facet of their life. Increased participation of women in political affairs leads to more female-centric legislations that take their interests and lived realities into considerations (Dawn Editorial, 2020).

\section{Challenges for Women's Political Participation}

Several impediments impact women's political participation in Pakistan. Social, economic, religious, and cultural factors are obstacles to the political empowerment of women in the country. The issues of gender discrimination remain unresolved, restricting women's roles in the domain of politics. The influential culture discourages women's role in politics in Pakistan (Bari, 2000). Women in Pakistan are subject to spiritual, racial, ideological, social, and economic issues. The social and cultural obstacles are affecting women's political participation. Men enjoy a dominant status in Pakistani society.

Pakistan is among the countries of the world where the gender gap is prevalent in all spheres of life. Women lag far behind men in all fields of life including education, finance, and healthcare. Pakistan's society is based on patriarchal norms which have their role in increasing issues disparity against women in different spheres of life. Women in Pakistan are struggling for equal opportunities and rights in the country. The barbarism in the form of rape and honor killing is still a gloomy picture of women in Pakistani society. The women in rural areas of the country are barred from using their political rights. (Kayser, 2013).

In Pakistan, there are still many hurdles in way of women taking part in politics. Women mainly with political backgrounds get the opportunity to have representation in the provincial or national assembly of the country. The female 
household members have a very minor role in the political process and male members dominate the political affairs. Factors which are responsible for the violence against female include shortcomings in the execution of legal procedures, insufficient support from law enforcement agencies and the judiciary; and the socio-economic hurdles in the way to women political empowerment in Pakistan. The religious setup and power structure of a male-controlled society can never be overlooked while studying women's empowerment in various domains of life, especially politics (Right Vision News, 2014). Socio-cultural practices and the economic dependency of women on the male counterpart of their household are also affecting women's role in the domain of politics in Pakistan. Besides, the low literacy rate of the female is another blocking factor in way of women's role in politics.

"There are structural concerns, such as patriarchy and issues of mobility, and until these are addressed it will not be possible to have the full participation of women in the political process, the $5 \mathrm{pc}$ rule for political parties was barely met and in many cases, it was met as a formality. Women were given tickets for unwinnable seats and not much support was provided to women in terms of resources and otherwise." (Kazmi, 2018, December 14).

The social status of women in urban and rural areas of the country have less difference even though women living in urban areas have more educational opportunities and play role in various fields of society (Najam \& Yusuf, 2013). Social suppression of women due to inherent gender discrimination, racial, feudalism, domestic violence, cultural and religious factors have minored women's role in politics. There is a various organization which is playing role in promoting and acknowledging the political, economic and social rights of women in Pakistan, but these still have partly effective to ensure the equality in the social system.

\section{Conclusion}

It is evident from the examined data that women's political role in Pakistan has gradually improved during the last two decades. It is mainly due to the rise in the 


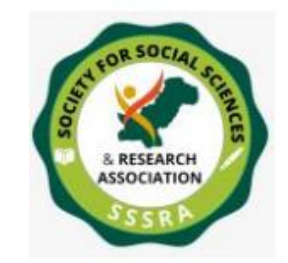

number of reserved seats for women in legislative assemblies. It is explored that power in some cases is being transferred from father to daughter instead of sons which is significant progress in the male-dominated society of Pakistan. Women are still less empowered as compared to men in the field of politics. But the gap is reducing, and that is a welcome change in the patriarchal society of Pakistan.

To promote female political participation, continuous and serious steps should be taken to increase their representation as well as their role as elected members of legislative bodies. In Pakistan, females with strong political backgrounds enjoy more representation while it is still difficult for ordinary women to enter into the political domain of the country. Though the present scenario is still not ideal, yet is quite satisfactory if compared with the whole world, especially the Muslim world. More women should be directly elected rather than reserved seats. The success of women while contesting general seats will play a significant role confidencebuilding process.

The past two decades have witnessed significant progress in terms of women's political participation in Pakistan. It is obvious from the analyzed period of Pakistan's political history, women's role political affairs of the country has increased, but filling the gaps needs more seriousness on the part of the government. The policies adopted by the Election commission of Pakistan are commendable. But it is high time to promote a political culture that encourages women's political participation. Political parties play a crucial role in shaping the political culture of a country. Political parties in Pakistan should take measures to encourage the participation of women in politics and enhance their representation in legislative bodies.

\section{Suggestions}

- Based on the findings of the study, it is noted that education is one of the impediments in women's political empowerment. The government should take serious steps to enhance the female literacy rate in the country. 
- Economic empowerment plays a significant role in women's political empowerment and legislative representation. The government should adopt effective strategies to eliminate the economic obstacles women are facing in Pakistan.

- The social status of women in rural areas needs more attention from the government. Concrete measures should be made to address the challenges women are facing in rural areas of the country. 


\section{References}

Akram , S, Azhar D M Basit D . (2020). Legislative Initiatives of 14th National Assembly of Pakistan: A Critical Analysis. Pakistan Social Sciences Review,4(1), 229-246, https://pssr.org.pk/article/legislative-initiatives-of14th-national-assembly-of-pakistan-a-critical-analysis.

Bari, F. (2000). Women in Pakistan: Country briefing paper. Asian Development Bank. https://www.adb.org/sites/default/files/institutionaldocument/32562/women-pakistan.pdf

Bano, S. (2009). Women in parliament in Pakistan: Problems and potential solutions. Women's Studies Journal, 23(1), 19.

Dawn Staff Reporter. (2020, January 22). Underrepresentation of women in politics highlighted. Dawn. https://www.dawn.com/news/1529724.

Dawn Editorial. (2020, July 6). Women and the Vote. Dawn. https://www.dawn.com/news/1567280 .

Free and Fair Election Network. (2018). Voter Turnout in GE-18. FAFEN Election Observation Report. https://fafen.org/wpcontent/uploads/2018/08/FAFEN\%E2\%80\%99S-Analysis-of-VoterTurnout-in-GE-2018.pdf.

Graff, I. (2003, June). Women representation in Pakistani politics: The quota systems under the Musharraf regime. In 1st International Conference on Women and Politics in Asia, Halmstad.

Kazmi, S. S. (2018, December 14). 2018 elections very significant from women's point of view: NCSW. Dawn. https://www.dawn.com/news/1451269. 
Kamray, A. (2020, September 15). For women in politics, Pakistan still lags behind. The Express Tribune. https://tribune.com.pk/story/2264059/forwomen-in-politics-pakistan-still-lags-behind.

Kayser, B. J. (2013). Politics Or Piety, The Women of Pakistan. [Doctoral Thesis.Drew University.]

Khan, A., \& Naqvi, S. (2020). Dilemmas of Representation: Women in Pakistan's Assemblies. Asian Affairs, 51(2), 286-306.

Khan, F. S. (2020, October 9). Women in Politics. The News International. https://www.thenews.com.pk/print/726526-women-in-politics.

Latif, A., Usman, D. A., Kataria, J. R., \& Abdullah, M. (2020). Female political participation in South Asia: A case study of Pakistan. South Asian Studies, $30(2)$.

Sattar, N. (2020, March 10). Women's Work. Dawn. https://www.dawn.com/news/1539668.

Women Development Departmnet, Government of the Punjab. (2021). Women Rights: Constitutional Provisions Regarding Fundamental Rights. https://wdd.punjab.gov.pk/women_rights.

World Bank. (2019). Population, female (\% of total population) - Pakistan. The World Bank-Group. https://data.worldbank.org/indicator/SP.POP.TOTL.FE.ZS?locations=PK 